\title{
Z dziejów kultury książki w Kamieńcu Podolskim w XVI-XVIII w.
}

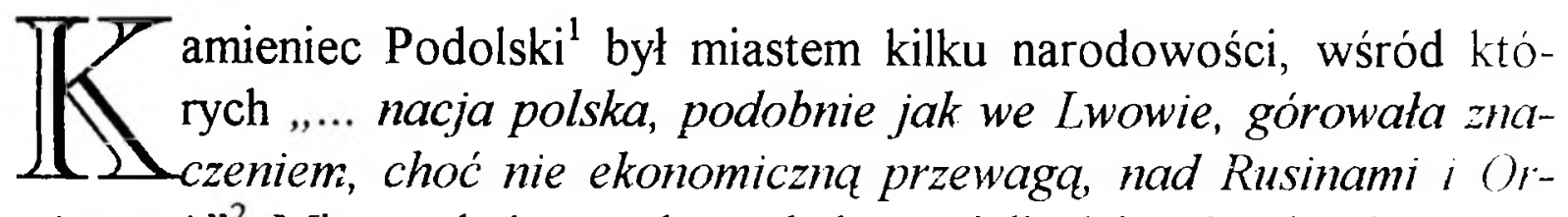
mianami." Miasto, które pod względem wielkości należało do grupy mniejszych miast, liczących od dwóch do dziesięciu tysięcy mieszkańców (w 1570 r. miało bowiem 645 domów), ${ }^{3}$ było potężną warownią niezdobyta przez wrogów do roku 1672 . W tym roku Kamieniec został opanowany przez Turków i okupowany do 1699 r. Mimo swego znaczenia wojskowego nie był pustynią kulturalna, chociaż, bez wątpienia, sprawy jego obrony absorbowały kamieńczan $w$ większym stopniu niż to miało miejsce w innych miastach. Częste napady wrogów nie dawały większych szans mieszkańcom województwa podolskiego, jak i jego stolicy, do stabilizacji życiowej i realizacji potrzeb kulturalnych, wśród których jedno z naczelnych miejsc zajmowało słowo mówione, pisane i drukowane. Oprócz znaczenia jakie posiadał Kamieniec jako graniczny gród warowny, by to niemały lokalny ośrodek rzemieślniczy oraz $\mathrm{w}$ większym jeszcze stopniı handlowy, o powiazzaniach międzynarodowych.

Niewiele jednak czasu można było poświęcić sprawom szeroko pojmowanej kultury, w tak zróżnicowanym środowisku wielonarodoivościowym. Owa wielokulturowość miasta w istotny sposób musiała w plynać na sprawy związane $z$ książką.

Przed wynalazkiem Gutenberga, a nawet jeszcze przez pewien czas po tym epokowym odkryciu, książka rękopiśmienna była produkowana przez miejscowych wytwórców. Szczególnie pod tym względem zwracają na siebie uwagę księgi ormiańskie. Najstarsza z nich, o której mamy wiadomości, to mszał ormiański, który został przepisany na Krymie w 1349 r. Na jego kartach w 1394 r. został odnotowany fakt podarowania go przez kupca Sinana. Ormiańska książka rękopiśmienna, przepisywana w Kamieńcu (szczególnie w XVI-XVII w.) pozostanie jako dowód wysokiej kultury miejscowej społeczności. Jak twierdzą niektórzy badacze

Z Badań Nad Polskimi Księgozbiorami Historycznymi,

t. 18. Warszawa 1997 
kodeksów, o znacznej liczbie skryptorów tekstów ormiańskich w Kamieńcu świadczą kolofony. ${ }^{4}$

Kodeksy były przechowywane w miejscowej katedrze ormiańskiej, ale po zajęciu przez Turków Kamieńca Podolskiego oraz wysiedleniu Ormian zostały rozproszone. Nieduża ich część znajduje się dziś w Petersburgu w Bibliotece im. Saltykowa-Szczedrina (przedtem Cesarska Biblioteka Publiczna), dokąd zostały zabrane w $1891 \mathrm{r}$. W tym czasie zostały wywiezione, oprócz 45 rękopisów, 54 ormiańskie najstarsze księgi drukowane. ${ }^{5}$ Czy były w zbiorach ormiańskiej społeczności Kamieńca książki łacińskie i polskie, trudno o tym na etapie dzisiejszych badań mówić. Sądząc po zbiorach lwowskich Ormian, druki te mogłyby być gromadzone również w Kamieńcu, przede wszystkim w środowisku duchowieństwa oraz przedstawicieli inteligencji świeckiej, np. reprezentantów palestry. ${ }^{6}$

\section{Księgozbiory instytucji kościelnych}

W skarbcu Kościoła Katedralnego pod wezwaniem Najświętszej Marii Panny w $1580 \mathrm{r}$. - jak świadczy o tym inwentarz ${ }^{7}$ - znajdowało się ponad dwadzieścia pozycji książkowych, głównie druków liturgicznych oraz kazań. Wśród nich dzieło Philippe'a Melanchtona Loci communes rerum theologicarum, zanotowane pod skróconym tytułem Loci teologici Philip. Melancht.

Przy tymże kościele w późniejszym czasie istniała biblioteka katedralna i kolegium wikariuszy (,Bibliotheca cathedralis et Collegii Vicariorum"). Jej inwentarz został spisany przy okazji wizytacji w $1741 \mathrm{r}$. dokonanej przez Wacława Hieronima Sierakowskiego, biskupa kamienieckiego ${ }^{8}$. Nie wiadomo, jaki był los księgozbioru, który przed zajęciem Kamieńca przez wojska tureckie istniał przy tej katedrze. W bibliotece katedralnej - według wspomnianego inwentarza - były przechowywane ksiażki: w zakrystii - liturgiczne (w liczbie 12); na chórze (4) oraz księgi kościelne (11) i kapitulne (148). Razem więc stanowiły skromną liczbę 175 książek. Księgi kapitulne znajdowały się w drewnianych szafach, niektóre z nich były oszklone. Oprócz ksiąg liturgicznych, kaznodziejskich oraz $\mathrm{z}$ dziedziny moralności, $w$ inwentarzu figurują druki z historii powszechnej i Polski, filozofii, prawa, piśmiennictwa antycznego (Cyceron, Plutarch, Klaudiusz Ptolemeusz, Galen i in, ;, głównie w języku łacińskim. 
Spora część książek była w języku polskim. Nie zabrakło książek z leksykografii (słownika Knapskiego oraz innych), arytmetyki, jak równiez $z$ innych dziedzin.

Większe księgozbiory były zgromadzone przy klasztorach. Nie o wszystkich jednak posiadamy wiadomości. Największa biblioteka znajdowała się przy Kolegium Jezuickim. Wiadomo, iż wielką zasługę przy jej organizacji położył biskup kamieniecki, bibliofil i mecenas - Jan Andizej Próchnicki, który zresztą sprowadził jezuitów do miasta nad Smotryczem jeszcze przed swoim przyjazdem w 1608 r. Próchnicki zaopatrzył ją w kilkaset dzieł ze wszystkich niemal dziedzin', ale po zajęciu miasta przez Turków zbiory te zostały rozproszone. Niektóre książki trafiły do Konstantynopola, gdzie były - jak się wydaje - przedmiotem handlu ${ }^{16}$. Trudno powiedzieć jak duża ich część została wywieziona z Kamieńca i czy powróciła razem z jezuitami w późniejszym czasie. Wiadomo jedynie, że w XIX i XX w. zachował się w mieście zespół druków miejscowej proweniencji jezuickiej, m.in. pochodzących $z$ daru biskupa.

Według spisu książek z 1773 r. $^{11}$, sporządzonego po kasacie zakonu jezuickiego, biblioteka kolegium liczyła ok. 660 pozycji książkowych w języku łacińskim, polskim, francuskim, niemieckim, greckim oraz starocerkiewnosłowiańskim. Była to głównie literatura $z$ różnych dziedzin religii. Jak zostało podane $w$ inwentarzu - zbiory gromadzono w następujących działach: concionatores (107 pozycji), literatura retoryczna (102), historia Kościoła (53), historia świecka (34), filozofia (29), matematyka (8), teologia dogmatyczna (37), teologia moralna (33), komentarze do Pisma św. (20), controversiae (41), prawo kanoniczile i świeckie (15), polityka i statystyka (27), asceza (30). Oprócz tego bliżej nie określonych książek w języku francuskim, niemieckim i greckim było 72 a innych - 41. Niektóre działy zawierały książki zaklasyfikowane do nich pomyłkowo, ale mimo to na podstawie inwentarza można sobie wyrobic pogląd na zawartość treściową biblioteki.

Wśród autorów literatury świeckiej znalazł się szereg antycznych pisarzy i poetów, m. in. przedstawiciele filozofii i literatury greckiej. a wśród nich Arystoteles, Platon, Hezjod, Arystofanes oraz literatury rzymskiej: Cyceron, Horacy, Owidiusz, Wergiliusz, Gelliusz, Tacyt i inni

Był to nieduży księgozbiór, zapewne jeden z najmniejszych będących w posiadaniu kolegiów jezuickich na terenie Rzeczypospolitej

Inne klasztory również posiadały księgozbiory składające się - jak należy przypuszczać - z co najmniej kilkuset woluminów: dominikan 
karmelici bosi ${ }^{13}$. Należy dodać, że do Kamieńca zostały przewiezione książki z biblioteki zlikwidowanego w 1784 r. lwowskiego Kolegium Teatynów i uległy rozproszeniu ${ }^{14}$. Być może, przynajmniej część tego księgozbioru znajduje się w Centralnej Bibliotece Naukowej Akademii Nauk Ukrainy w Kijowie, skoro tam znalazł się jego inwentarz.

\section{Księgozbiory duchowieństwa}

Właścicielami jednych $\mathrm{z}$ większych księgozbiorów byli biskupi kamienieccy, a wśród nich znani miłośnicy książek jak Leonard Słonczewski, Jan Andrzej Próchnicki oraz Paweł Piasecki (zm. 1649) posiadający superekslibrisy. Jednak ich krótki pobyt nad Smotryczem nie wskazuje raczej na to, że utrzymywali przy sobie całe księgozbiory. Najbiedniejsze ze wszystkich biskupstw w Rzeczypospolitej - biskupstwo kamienieckie było pierwszym szczeblem do kariery biskupiej niejednego duchownego, który musiał przypuszczać, że jego pobyt w tym mieście będzie raczej krótki. Prawdopodobnie inni duchowni (jak na przykład Melchior Infantinus, o czym niżej) również nie sprowadzali do Kamieńca wszystkich książek, będących $w$ ich posiadaniu, ale tylko druki potrzebne im głównie do pracy.

Pewien czynnik pozytywny w zakresie zbieractwa książkowego - jak należy mniemać - wniósł do miejscowego środowiska Jan Andrzej Próchnicki (od 1607 r. do 1614 r. biskup kamieniecki) ${ }^{15}$, znany ze szczególnego stosunku do ksiażki. Ten bibliofil, posiadający w późniejszym czasie kilkanaście odmian superekslibrisu, podarował bibliotece jezuitów kamienieckich doborowy zestaw książek (,biblioteke zasobna $w$ dziela $z$ wszystkich dziedzin") oznaczonych jego znakami własnościowymi.

Z XVIII w. znana jest również biblioteka prywatna biskupa kamienieckiego, Mikołaja Dembowskiego ${ }^{16}$.

Podobnie znane są nazwiska kanoników, prałatów i innych duchownych kamienieckich, którzy zbierali książki. Wśród nich na uwagę zasługuje Jakub Wierzbieński, proboszcz katedry kamienieckiej w drugiej połowie XVI w. posiadajacy własny superekslibris. Nie wiadomo czy był nim późniejszy kanonik lwowski o tym samym imieniu i nazwisku (zm. ok. 1596 r.), również właściciel księgozbioru. Proboszcz ten posiadal książki $m$. in. $z$ dziedziny arytmetyki $i^{17}$. Księgozbiory zgromadzili tak- 
że między innymi kanonicy: Augustyn Wolski, znaczący swój zbiór superekslibrisem oraz Mikołaj Lichnar ${ }^{18}$. Z późniejszego okresu znamy nazwiska następujących kanoników gromadzących książki: Szymona (którego nazwisko udało się odczytać jedynie częściowo: Arystopho... ${ }^{19}$ ) Grzegorza Augusta Macedońskiego ${ }^{20}$, Pawła Suskiego ${ }^{21}$. W zbiorach biblioteki katedralnej kamienieckiej znalazły się książki, które wcześniej należały do innych kanoników kamienieckich, $m$. in. do doktora teologii Jerzego Antoniego Ferensa Pakorzewskiego (?) ${ }^{22}$.

Właścicielem ok. 200 książek (sądząc na podstawie wartości oszacowanego księgozbioru - 500 złp) był zmarły ok. 1605 r. dziekan kamieniecki Melchior Infantinus. Książki jego znajdowały się we Lwowie w depozycie u Stanisława Potelickiego, ślusarza, do którego miał pretensje Maciej Szaniawski („nobilem”) jako spowinowacony z dziekanem jego spadkobierca. Pozwany ślusarz stwierdził w sądzie, że dziekan za trzykrotnym pobytem we Lwowie brał ze skrzyni książki, resztę zaś w liczbie około 40 podarowal jego synowi ${ }^{23}$.

Inny dziekan, Szymon Krzysztofowicz był właścicielem Biblii wydanej w Lyonie w końcu XVI w., którą następnie - sądząc z zapisu pozostawionego na karcie książki - podarował klasztorowi w Złoczowie ${ }^{24}$.

Wśród bakałarzy kamienieckich żyjących na początku XVII w. znajdowali się ksiądz Wojciech Russius, prefekt szkoły katedralnej, który prawdopodobnie pochodził z Biecza, gdyż pozostawił w tym mieście majątek ${ }^{25}$.

\section{Księgozbiory mieszczan}

Książka i księgozbiory mieszczan w miastach nie należących do największych, takich jak Kamieniec, nie zostały zbadane w interesujacym nas okresie. Nie mamy więc pewnego punktu odniesienia, tak ważnego dla charakterystyki zbieractwa książkowego w różnych ośrodkach mieszczańskich dawnej Rzeczypospolitej. Charakter kresowego miasta, tym bardziej o wyraźnym znaczeniu obronnym, nie sprzyjał zbieractwu książek, a mieszczaństwo raczej nie miało większych ambicji kulturalnych, mimo istnienia ośrodków kultury religijnej: kościołów, klasztorów, a przede wszystkim biskupstwa. Inaczej było w innych miastach podobnej wielkości, ale położonych dalej na zachód. jak np. w Jarostawiu, Sambe rze, a szczególnie w Przemyślu. Mieszkancy tych miast skupiających 
dziej wykształconych obywateli o wyrobionych ambicjach kulturalnych musieli posiadać większe księgozbiory.

Ksiażka, jak wiadomo, powinna była znajdować się w domu ludzi wykształconych $\mathrm{i}$ to raczej na poziomie wyższym niż elementarny. W Kamieńcu nie brakowało takich mieszkańców; najczęściej byli to bakałarze, którzy piastowali różne stanowiska w mieście. Wśród nich znajdowali się przedstawiciele miejscowej palestry, rektorzy szkoły oraz lekarze, w kręgu których książka pełniła rolę utylitarną.

Spośród bakałarzy żyjących $w$ drugiej połowie XVI w. można by wymienić Jakuba Chocimskiego, wójta z prawa niemieckiego (w 1560 r.), a następnie rajcy kamienieckiego $(1561)^{26}$, Jana Modzelewskiego, rektora szkoły $(1564)^{27}$, Jana Dzięcielewskiego, pisarza miejskiego $(1571)^{28}$, Błażeja, lawnika przysięłłego (1571), następnie burmistrza (1581) Jana Kmity, rektora szkoły, notowanego w aktach jako "nobilis" $(1596)^{30}$ oraz Szymona Albiniusa (Albin) z Pilzna, bakałarza sztuk i filozofii, ławnika a następnie pisarza wójtowskiego, posiadającego księgozbiór (o czym niżej).

Za bardziej wybijającego się wśród bakałarzy kamienieckich - jak można sądzić $\mathrm{z}$ zapisu pozostawionego na karcie księgi miejskiej ${ }^{31}$ - należałoby uważać Melchiora Balaskiego (1604), syna Błażeja, rajcy kamienieckiego.

W księgach miejskich Kamieńca Podolskiego byli wymieniani: pisarz Walenty ( $w$ latach $1520-1536)^{32}$; Stanisław, pisarz miejski ${ }^{33}$; Jan, pisarz grodzki $^{34}$; Andrzej, pisarz miejski (1559-1564), żonaty z Anastazją; Maciej Czwiklicz, notariusz przysięgły ${ }^{36}$; Jan G. Felsztyński (1591-1606), zapewne właściciel księgozbioru i superekslibrisu i Marcin Papusius (1612 r.), notariusz rady miasta ${ }^{37}$. Wśród XVII-wiecznych pisarzy występuje $\mathrm{m}$. in. Tomasz Bakowicz wybrany w $1645 \mathrm{r}$. na to stanowisko ${ }^{38}$.

W grupie miejscowych pisarzy lub ,podpisków" będących na usługach zarówno urzędów miejskich jak i innych (np. grodzkiego) i legitymujacych się wykształceniem (czasem byli to ci sami wspomniani bakałarze), znajdowali się miłośnicy poezji i wierszopisowie. Świadczą o tym pozostawione na kartach miejskich ksiąg sądowych wiersze układane pod wpływem twórczości antycznych autorów Horacego, Owidiusza i in. ${ }^{39}$

Nie brakowało więc w Kamieńcu ludzi wykształconych, studiujących najczęściej w krakowskiej Alma Mater ${ }^{40}$ w większości kończących swoje studia $\mathrm{z}$ tytułem bakałarza. 
W pierwszym dziesięcioleciu XVII w. wśród miejscowych urzędników nie zabrakło pewnych inicjatyw związanych $z$ uporządkowaniem i oprawą akt miejskich. ${ }^{41}$ Szczególnie należy podkreślić zasługi wójta Stanisława Sambora, kosztem którego zostały oprawione księgi miejskie, o czym świadczą odpowiednie napisy, wytłoczone na okładzinach ksiag przez miejscowego lub wędrownego introligatora. Być może, że Stanisław Sambor posiadał własny księgozbiór, dla którego zamówił tłok superekslibrisu.

Podobny zwyczaj upamiętnienia swoich zasług, był znany w tym micście już wcześniej. W $1581 \mathrm{r}$. bowiem została zakupiona księga (Acła resignationum) za lata 1581-1616, która została przeznaczona do spisywania spraw miejskich. Zakupu za wspólne pieniądze ławników kamienieckich (co było zjawiskiem znanym również w innych miastach) dokonal Stanisław Długosz, wójt, o czym świadczy odpowiedni zapis. ${ }^{42}$

$\mathrm{Na}$ marginesie tych spraw warto dodać, że mocno ucierpiały w czasie okupacji Kamieńca przez Turków urzędowe księgi grodzkie i miejskie będące cennym źródłem do poznania dziejów książki i kultury w środowisku mieszczańskim. ${ }^{43}$ Gorszy los spotkał inne ważne źródło, mianowicie księgi metrykalne miasta, które zostały zatracone również $w$ tym samym okresie. Pozostały - jak świadczą o tym osiemnastowieczne źródła - jedynie metryki zaczynające się od $1699 \mathrm{r}^{4+}$

Podniesieniu ogólnej wiedzy o świecie, zainteresowaniu historią czy też geografią sprzyjały kontakty mieszczan Kamieńca z krajami ościennymi, głównie z Mołdawią i Wołoszczyzną. Miasto gościło czasem posłów $z$ tych księstw, jak to miało miejsce w r. $1645 .^{45}$ Nie była bez znaczenia również obecność kupców z różnych stron Europy czy też Azji, a w szczególności ruchliwych Ormian pochodzących z miejscowej licznej diaspory, jak również ich krewnych z innych miast Rzeczypospolitej.

Można prześledzić ślady pobytu w Kamieńcu pracowników ruskiej książki (drukarzy, introligatorów) niosących pomoc drukarniom na terenie Mołdawii i Woloszczyzny. Pewna znajomośc prawa potrzebna była rownież palestrze ruskiej, prowadzacej sprawy i księgi prawa. Jej przedstawi. cieli można było spotkać w miastach, gdzie odbywały się duże jarmarí podczas których odbywała się również sprzedaż książek, $m$. in w Jarosławiu. W tym mieście przebywał w czasie jarmarku w 1647 ; Maciej Tołoczko, pisarz prawa ruskiego z Kamieńca Podolskiego ${ }^{40}$

Należałoby podkreślić znaczenie kontaktów mieszkańców stolicy

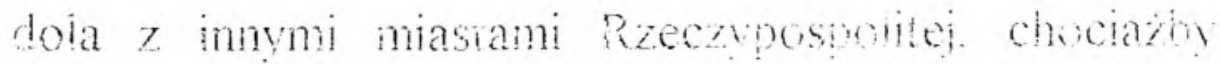


a może też z Lublinem, które były ośrodkami produkcji i rozpowszechniania książki polskiej na wschodnich terenach kraju. Ze Lwowa do Kamieńca dostarczano $m$. in. książki oraz papier ${ }^{48}$, ale nie znamy skali tego zjawiska. Wiadomo również, że księgarze lwowscy docierali na Podole, np. na jarmarki do Baru. ${ }^{49}$ Kamieniec, jako duży ośrodek handlowy, gdzie jarmarki cieszyły się sporą frekwencja mógł być nie tylko punktem docelowym, ale również tranzytowym niektórych towarów związanych z produkcją książki, jak i gotowych książek, do księstw Mołdawii i Wołoszczyzny, i to zarówno książki polskiej jak i ruskiej.

Podczas gdy $w$ innych miastach największe księgozbiory posiadali lekarze, w Kamieńcu nie widać tej tendencji. W inwentarzu wdowy po doktorze medycyny Mikołaju, który był również ławnikiem przysięgłym (zm. przed 1589 r.), figurowało kilka książek, m. in. Opera ojca medycyny Hipokratesa, dzieła Paracelsusa, jak również inne ,philosophiae et medicinae xsięgi niebosczykowskie". ${ }^{50}$ Wdowa, jak się wydaje, w krótkim czasie wyszła po raz drugi za mąż za Leonarda Sterna i wtedy być może został sporządzony spis ruchomości. Nie wiadomo jednak czy były to wszystkie księgi kamienieckiego medyka.

Inny inwentarz, spisany w $1606 \mathrm{r}$. po śmierci wzmiankowanego już Szymona Albina, wykazał osiemnaście drukowanych książek oraz jedną rękopiśmienna, „w którq on sam nieboszczyk począt pisać" . "Wśród ksiażek znajdowały się przeważnie dzieła antycznych pisarzy: Ksenofonta, Plutarcha oraz Owidiusza, Cycerona, Horacego, Terencjusza, rzymskich historyków Salustiusza i Justyna, jak również książki z dziedziny epistolografii, gramatyki, dialektyki $\mathrm{i}$ in.

Wśród inwentarzy majątkowych rajców kamienieckich natknęliśmy się na spis książek Grzegorza Kudlicza, który zgromadził zaledwie dziesięć ksiażek (,[...] xiag polskich czworo, xiqg mniejszych sześcioro"). ${ }^{52}$ Inwentarze ruchomości innych rajców, jak Macieja Fabiszka (z 1565 r.), Jakuba Chocimskiego (zm. ok. 1573) czy Stanisława Mytnikowicza (zm. ok. 1589) ${ }^{53}$ nie zarejestrowały żadnych druków.

$Z$ rodziny zbieraczy książek pochodził, wcześniej wspomniany, pisarz kamieniecki Jan G. Felsztyński. Członkowie tej rodziny posiadali znak ksiażkowy z herbem (może gmerkiem) z wyobrażeniem kwiatu (róża?) i taki właśnie znak został odbity na dolnej okładzinie kamienieckiej księgi miejskiej. ${ }^{54}$ Podobny znak należący do bliżej nieznanego Walentego G. Felsztyńskiego ${ }^{55}$ reprodukuje E. Lauçevičius sugerując, że to może być herb "Poraj". Wydaje się, że przechowywane $w$ bibliotekach książki 
z zapisem proweniencyjnym „Joannes Felsztyniski meus [...] possessor, ${ }^{, 57}$ należy przypisać pisarzowi kamienieckiemu.

Książka znajdowała się nie tylko w posiadaniu miejscowej ludności, ale również była własnością przyjezdnych. W r. 1563 chirurg kamieniecki, Filip Szelhamer zeznał przed miejscowym urzędem, że przejał skrzynkę, która była własnością Hanusza („dicti Tribenbach de Kieszmark"), od Sebastiana, kamienieckiego puszkarza zamkowego - za dług. W skrzyni znajdowało się $\mathrm{m}$. in. "xiqzek pięczori malich" 58 Nie wiadomo czy Hanusz z Kieżmarku na Spiszu, nazwisko którego pisarz zdaje się przekręcił, czytał książki w podróży czy handlował nimi.

\section{Księgozbiór Jana i Józefa de Witte’ów}

Pośród osiemnastowiecznych posiadaczy księgozbiorów wyróżniała się biblioteka Jana de Witte (zm. 1785), architekta i komendanta Kamieńca oraz jego syna Józefa (zm. 1815) ${ }^{59}$ Niektóre książki Witte’ow, na których widnieje podpis żony Józefa - Zofii, $2^{0}$ voto Potockiej, znalazły się w zbiorach biblioteki tulczyńskiej. Dziś druki i rękopisy z biblioteki Witte'ów przechowywane są w bibliotekach Łańcuta, Krakowa, Torunia i Wrocławia. ${ }^{60}$ Jan de Witte kupował książki we Lwowie (w 1760 r.), gdzie nabył za 10 złp gdańskie wydanie Kroniki Jana Herburta oraz w Warszawie (w 1762 r.), gdzie kupił Szymona Starowolskiego Vitue antistitum Cracoviensium... ${ }^{61} \mathrm{~W}$ jego bibliotece, nie znanej wielkości, znajdowały się książki z różnych dziedzin, głównie z zakresu architektury, nauk matematyczno-przyrodniczych, astronomii $\mathrm{i}$ in, a wśród nich pochodzące z biblioteki Józefa Andrzeja Załuskiego, biskupa kijowskiego. W posiadaniu Józefa de Witte, oprócz znanych dotychczas kilkudziesieciu druków, głównie z zakresu historii, teologii i architektury znajdowal sie druk Pawła Kuhna Arcus pacis... (Kraków 1635) należący niegdys do króla Władysława IV, o czym świadczy królewski superekslibris. ${ }^{62}$

Pełny przegląd księgozbiorów w Kamieńcu Podolskim pozrioli w przyszłości określić miejsce tego miasta na mapie zbieractwa książ́owego dawnej Rzeczypospolitej. Już dzisiaj jednak można stwierdzic, że największe księgozbiory klasztorne zawierały po kilkaset dzici, a mieszczańskie nie przekraczały dwudziestu. Działalność zaś niektórycin miłośników książki spośród osób duchownych była zbyt krótka, by mozna 
było wnioskować o jakimś znaczącym oddziaływaniu ich księgozbiorów na otaczające środowisko.

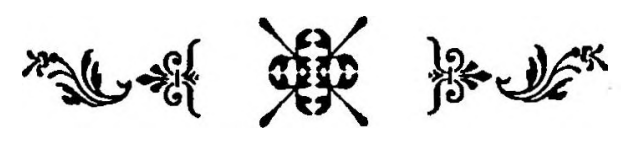

Przypisy:

${ }^{1}$ Historii miasta poświęcono dotąd dwie główne pozycje. Jedna $\mathrm{z}$ nich to praca A. Prusiewicza: Kamieniec Podolski. Szkic historyczny. Kijów-Warszawa 1915, a druga to: E. Siecinskij: Gorod Kamieniec Podolskij. Istoriczeskoje opisanije. Kijew 1895.

${ }^{2} \mathrm{M}$. Bogucka, H. Samsonowicz: Dzieje miast i mieszczaństwa w Polsce przedrozbiorowej. Wroclaw 1986, s. 468.

${ }^{3}$ Tamże, s. 371, 375.

${ }^{4}$ J. R. Daszkiewicz: Armianskaja kniga na Ukrainie w XTII stoletii. W: Kniga. Issledowanija i matieriały, t. VI. Moskwa 1962, s. 147-148.

${ }^{5}$ Tamże, s. 166.

${ }^{6}$ Nazwiska pisarzy sądu ormiańskiego spotykamy nie tylko na kartach ksiag kamienieckich, ale również $w$ innych miastach, np. we Lwowie. Pod $1611 \mathrm{r}$. w lwowskich księgach figuruje nazwisko Jakuba Iwaszkowicza, pisarza sądu ormiańskiego w Kamieńcu (Centralne Państwowe Archiwum Historyczne Ukrainy we Lwowie (dalej CPAHL), fond. (f.) 52, opis (op.) 2, sprawa (spr.) 392, k. 653

${ }^{7}$ Materialy źródtowe do dziejów kultury i sztuki XVI-XVIII w. Opr. M. Gębarowicz. Wroclaw 1973, s. 301.

${ }^{8}$ Biblioteka PAN w Krakowie, rkps 2002, s. 134-135, 142-143, 146-152.

${ }^{9}$ M. Gębarowicz: Jan Andrzej Próchnicki (1553-1633). Mecenas i bibliofil. Szkic $z$ dziejów kultury w epoce kontrreformacji. Kraków 1980, s. 60, 63.

${ }^{10} \mathrm{M}$. Sipayllo: O metodzie badań proweniencyjnych starych druków. W: $Z$ Badań Nad Polskimi Księgozbiorami Historvcznvmi, z. l. Red. B. Bieńkowska. Warszawa 1975, s. 199.

${ }^{11}$ Biblioteka Narodowa w Warszawie, rkps 6939 III, k. 36-39.

${ }^{12}$ A. Prusiewicz: Biblioteki na Podolu i ich exlibrisy (Przyczynek do dziejów kultury polskiej na kresach). W: Exlibris, z. IV: 1922. s. 75.

${ }^{13}$ Por. pochodzące ze zbiorów bibliotcki karmelitów kamienieckich Homiliae Johanna Ecka (Kolonia 1538), znajdujące sic̨ dzisiaj we Lwowie (Katalog paleotipow iz fondow Lwowskoj naucznoj bibliotieki im. W'. Stiefanika AN USSR. Sostawitiel R.S. Charabadot, R.M. Biganskij. Kijew 1986. nr 265) oraz Rózaniec pospolicie Różany wianek Maryjej Matki Bożej. Kraków 1583 (w Bibliotece ZNiO we Wroclawiu. por. M. Bohonos: Katalog starych druków Biblioteki Zakladu Narodowego im. Ossolinskich. Polonica wieku .XVI. Wrocław-Wars7ana-K raków 1965. ni 926). 
${ }^{14}$ Por. J.R. Daszkiewicz: Armianskaja kniga..., s. 166; Centralna Biblioteka Naukowa AN Ukrainy w Kijowie, Dział Rękopisów, sygn. I 6450 (E. Różycki: Materiaty żródlowe do dziejów polskiej ksiażki w archiwach i bibliotekach Lwowa, Kijowa, Minika i Wilna. W: Roczniki Biblioteczne, R. XXXI: 1987, z. 2, s. 311).

${ }^{15} \mathrm{O}$ nim zob. M. Gębarowicz: Jan Andrzej Próchnicki...

${ }^{16}$ A. Prusiewicz: Biblioteki na Podolu..., s. 74.

${ }^{17} \mathrm{Sa}$ to oprawione w jednym klocku Frisiusa Gemmy Arithmeticae practicae methodus facilis... (Wittenberga 1544), Jana z Łańcuta Algorithmus linealis (Kraków b. r.) oraz Bernarda Wojewódki Algorytm (Kraków 1553). Por. R. Kotula: Wtaściciele rękopisów i starodruków zbiorów wielkopolskich Z. Czarneckiego. Lwów 1929, s. 75; Katalog paleotipów..., nr 338 .

18 Por. Katalog proweniencji Biblioteki Uniwersytetu Warszawskiego (sygn Sd. 713.550 [1,2]: 7.4.2.48).

${ }^{19}$ Posiadal książke Krzysztofa Jana Hartknocha wytłoczoną w Jenie w 1678 r. pt. Respublica Polonica duobus libris illustrata... (Por. Katalog starych druków Biblioleki Zaktadu Narodowego im. Ossolińskich. Polonica wieku XTII, t. I. Opr. B. Górska i W. Tyszkowski. Wroclaw 1991: t.2-5. Opr. W. Tyszkowski. Wroclaw 1992-1994. nr 2499,egz c).

${ }^{20}$ Do niego należało dzielo Jana Nadasiego pt. Annus coelestis Jesu Regi el Mariac Reginae sanctique omnibus... Editio nova.. Pars $1-4$, wydane $w$ Toruniu w $1696 \mathrm{r}$. (Katalog starych druków..., t. 4. Opr. W. Tyszkowski. Wroclaw 1994, nr 4716, egz. b)

${ }^{21}$ Posiadal książkę wydana w Warszawie w 1646 r. pt. Acta conventus Thorunensis: celebrati anno 1645... (Kalalog starych druków..., t. 1. Opr. B. Górska i W. Tyszkowski. Wroclaw 1991, nr 42).

${ }^{22}$ Bylo to dzielo Jana Herburta Statuta Regni Poloniae, Gdańsk 1620. Książka ta pó\%niej znalazla się $w$ bibliotece seminarium rzymskokatolickiego w Kamicńcu (zamkniętego w 1866 r.), jak świadczą zapisy na kartach druku.Dziś druk ten znajduje się w Bibliotece Centralnego Państwowego Archiwum Historycznego Ukrainy we Lwowie - sygn. 108.

${ }^{23}$ CPAHL, f. 52, op. 2, spr. 389 . k. 1927 (1605 r.).

24 Biblioteka Zakladu Narodowego im. Ossolińskich we Wroclawiu, S!gn XVI.0.9599.

25 Tamże. spr. 19, k. 229.

${ }^{26}$ Centralne Państwowe Archiwum Historyczne Ukrainy w Kijowie (dalej CPAHK). f. 39 - Magistrat miasta Kamieńca, op. 1, spr. 6, k. 92v, 93v, 122v.

27 Tamże. spr. 6, k. 264 (,honorabilis et nobilis Joannes Modzeliow'ski artium baccalaureus et rector scholae ac contubernii Camenecensis").

${ }^{28}$ Tamże, spr. 7, k. 1 (,nobilem. Joannem Dzienczilowski [.../ artium liberalium baccalaureum, notarium civilem (amenecensem").

${ }^{29}$ Tamże, spr. 7. k. 20; spr. 9, k. 144v.

${ }^{30}$ Tamże. spr. $18, \mathrm{k} .149 \mathrm{~V}$.

31 Tamże. spr. 19, k. 333 (,.,...] ingenuus ac eruditus Melchior Balasky artium liberalium et philosophiae baccalaureus, filius spectabilis et famati olim Blasii artium liberalium baccalcaure chis et consulis (amencensis"). 
32 Tamże, spr. 2.

33 Tamże, spr. 6. Synem jego i Malgorzaty był Jan, franciszkanin (Tamże, spr. 6, k. $154 \mathrm{v}, 1562$ r.).

${ }^{34}$ Tamże, spr. 2.

${ }^{35}$ Tamże, spr. 6, k. 49, 88, 155.

${ }^{36}$ Tamże, spr. 6, k. 229v.

${ }^{37}$ Tamże, spr. 9, k. 175; spr. 13, k. 145; spr. 23, k. 37; CPAHL, f. 52, op. 2, spr. 257, k. 655.

${ }^{38}$ CPAHK, f. 39, op. 1, spr. 38, k. 1v. Być może do niego należy wykonanie czerwonym atramentem ozdobnych naglówków w księgach urzędu burmistrzowskiego (por. tamże, spr. 38).

${ }^{39}$ Por. tamże, spr. 6 (księga za l. 1559-1566), k. 1-lv.

${ }^{40}$ Problematyka miejsca studiów mieszczan kamienieckich nie zostala zbadana. Wiadomo np., że studiowal w Akademii Krakowskiej pochodzący z Kamieńca Blażej, syn Andrzeja, później rajca miejski (Album studiosorum Universitatis Cracoviensis, t. III (Ab anno 1551 ad annum 1606). Editionem curavit A. Chmiel, Cracoviae 1904. s. 37.

${ }^{41}$ Por. E. Różycki: Oprawy ksiag archiwalnych źródtem do historii bibliofilstwa (na przykładzie b. województw podolskiego i ruskiego Rzeczypospolitej). W: Roczniki Biblioteczne, R. XXII, 1978, z. 3-4, s. 431.

42 „Praesentem librum Resignationum [...] famatus Stanislaus Dlugosz, ciuitatis eiusdem aduocatus ordinarius aere communi dominorum scabinorum comparauit [...]" (CPAHK, f. 39, op. 1, spr. 13, k. 1, 1581 r.)

${ }^{43} \mathrm{Na}$ kartach ksiag kamienieckich, które zostały przez autora tych slów przebadane do końca XVII w., znalazłem taki oto wspólczesny zapis: ,4kta kamienieckie odszukane od Turczyna [...], których in numero 19" (CPAHK, f. 39, op. 1, spr. 45 (księga za 1. 1700-1703), k. 28v.

${ }^{44}$ Były to, jak widać $\mathrm{z}$ akt wizytacyjnych biskupa kamienieckiego Wacława Hieronima Sierakowskiego z 1741 r., następujące metryki: Libri baptisatorum za lata: 1699-1712, $1713-1724,1706-1710,1725-1735,1735-1741$, copulatorum: 1699-1724, 1713-1718, 1725-1737, 1737-1741, mortuorum: 1725-1737. 1737-1741, bannorum: 1737-1741 (Biblioteka PAN w Krakowie. rkps 2002, s. 143).

${ }^{45}$ CPAHK, f. 39, op. 1, spr. 38, k. 17v.

${ }^{46}$ Archiwum Państwowe w Przemyślu. Akta m. Jaroslawia, sygn. 34. k. 613.

${ }^{47}$ Na katolickie mieszczaństwo kamienieckie. ıśród którego znajdowali się przedstawiciele rodów pochodzących z Sambora. Felsztyna, Biecza i innych miast i miasteczek czerwonoruskich i małopolskich, oddziaływala w znacznym stopniu kultura mieszczańska Lwowa. Podobnie jak lwowianie i inni mieszczanie, niektórzy mieszkańcy Kamieńca posiadali gmerki czyli herby mieszczańskie. które dowodzily świadomości odrębności tego stanu, ale też chęci naśladownictwa szlachty. Niektóre z nich znalazly się na kartach miejskich ksiagg kamienicckich. jako świadectwo kultury miejscowego środowiska mieszczańskiego (Por. CPAHK. 1. 39, op. 1, spr. 7. k. 372v (1574 r.)).

${ }^{48}$ Por. E. Różycki: Z dziejów ksiqżki we Lwowie w XIII wieku. Studia nad introligatorstwem $i$ handlem ksiqzkq, Katowice 1991, s. 102. Należy podkreślić pryy tym.

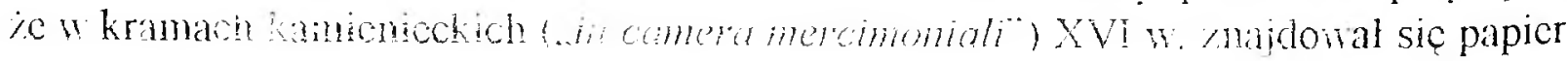


w niedużych ilościach, co zostało odnotowane w $1561 \mathrm{r}$. (,Item papyri pro florenis duobus gros[s] is viginti quat[t]uor", CPAHK, f. 39, op. 1, k. 109v).

${ }^{49}$ E. Różycki: $Z$ dziejów ksiażki..., s. 185.

${ }^{50}$ CPAHK, f. 39, op. 1, spr. 16, k. 49. Lekarz Mikołaj jest również notowany w innych aktach w 1. 1571-1581 (Tamże, spr. 7, k. 52 (1571 r.), 384v (1575 r.); spr. 9, k. 62v (1581 r.)).

${ }^{51}$ Tamże, spr. 23, k. 95v. Por. E. Różycki: Nieznane szczegóły z życia biatoruskiego drukarza Spiridona Sobola.W: Rocznik Biblioteki Narodowej, T. IX, 1974, s. 293: tenże, Stan i zadania badań nad dziejami księgozbiorów mieszczan lwowskich . $17 \%$ XVII w. W: Roczniki Biblioteczne, R. XXIII, 1979, z. 2, s. 10 (wykaz książek).

${ }^{52}$ CPAHK, f. 39, op. 1, spr. 38, k. 79v.

${ }^{53}$ Tamże, spr. 6, k. 302v-303; spr. 7, k. 24v-25, 253; spr. 16, k. 19v.

${ }^{54}$ Por. E. Różycki: Oprawy ksiag archiwalnych.., s. 432, fot. 5.

${ }^{55}$ Być może, że był to bakałarz filozofii, rektor szkoly parafialnej w Stryju Walenty z Felsztyna (Por. A. Prochaska: Historia miasta Stryja, Lwów 1926, s. 80).

${ }^{56}$ E. Lauçevičius: XV-XVIII a. knygy ifišimai Lietuvos bibliotekose, Vilnius 1976. nr 265.

${ }^{57}$ Por. druk: Accursius Franciscus: Casus in terminis super novem libris Iustiniani codicis [Argentorati, 1483] z zacytowanym napisem proweniencyjnym. Książka znajdowała się w Bibliotece Uniwersyteckiej we Lwowie (Por. E. Barwiński: Katalog inkunabutów Biblioteki Uniwersyteckiej we Lwowie, Lwów 1912. nr 1).

${ }^{58}$ CPAHK, f. 39, op. 1, spr. 6, k. 263.

${ }^{59} \mathrm{O}$ tej bibliotece pisano już w kilku pracach. Zob. m. in.: Stownik pracowników ksiqzzki polskiej. Suplement. Warszawa-Łódź 1986, s. 232-233 (H. Tadeusiewicz); Z. Rewski: Biblioteka architekta Jana de Witte oraz syna jego Józefa.W: Biuletyn Historii Sztuki, 1949, R. 11, nr 1/2, s. 160-165; M. Strutyńska: Stare druki prow'eniencji Potockich z Tulczyna w zbiorach Biblioteki Uniwersytetu Mikotaja Kopernika w Toruniu. W: Z Badań Nad Polskimi Księgozbiorami Historycznymi. Wyniki i perspektywy. Red. B. Bieńkowska, Warszawa 1992, s. 161 i nn.

${ }^{60}$ Z. Rewski: Biblioteka architekta..., s. 160 i nn.; M. Strutyńska: Stare druki..., s. 161 i nn.; Kraków, Biblioteka Czartoryskich, rkps 1275, 1176; Katalog starych druków... Opr. W. Tyszkowski, t. 3. Wroclaw 1993, nr 3714 egz. c; t. 4, nr 4391.

${ }^{61}$ M. Strutyńska: Stare druki..., s. 180, 197.

${ }^{62}$ Katalog starych druków... Opr. W. Tyszkowski, t. 3. Wroclaw 1993, nr 3714 egz. c. 